\title{
The Psychological Trauma on Boko Haram Victims in Nigeria: Conflict Resolution Perspective
}

\author{
Isaac Terungwa Terwase ${ }^{1}$
}

Asmat-Nizam Abdul-Talib²

Knocks Tapiwa Zengeni²

Joyce Mcivir Terwase ${ }^{3}$

${ }^{1}$ Ghazali Shafie Graduate School of Government, College of Law, Government and International Studies, Universiti Utara Malaysia, 06010 Sintok, Kedah, Malaysia Corresponding Author: isaacterwase1@gmail.com ${ }^{2}$ School of International Studies, College of Law, Government and International Studies, Universiti Utara Malaysia, 06010 Sintok, Kedah, Malaysia ${ }^{3}$ Department of Psychology, Benue State University, P.M.B. 102119, Makurdi, Nigeria

Doi:10.5901/mjss.2015.v6n6s4p519

\section{Abstract}

The Nigerian State before 1999 was ruled by the military for a very long period of time ranging from 1966-1979, and 1983-1999 they have stayed in power and control of Nigerian leadership. Within the said periods, the country was mostly led by the Northern leadership especially from 1983-1999 where leaders such as Buhari 1983-1985, Babangida 1985-1993, Abacha 1993-1998 and Abubakar 1998-1999 were all from the North. On the 29th of May, 1999 ushered in the return to democratic rule and power was shifted to the Southern part of the country under the leadership of Obasanjo 1999-2007. There was in place the principle of zoning and rotation of power between the North and South so as to promote the principle of peace, fairness, equity and justice as it was enshrined within the constitution of the ruling party, the PDP. May 29th, 2007 brought in another power shift from the South to the North through the leadership of Yar'Adua, who later died in office on the $5^{\text {th }}$ of May, 2010. Thus, the Vice-President took over power and it returned to the South, he contested in 2011 elections, was opposed by some quarters from the North where violence broke out and the Boko Haram became a tool as posits by late Gen. Andrew Azazi. The objective of the paper is to seek redress on how the conflict can be resolved and to bring to the fore the psychological trauma that the victims have undergone. The paper recommends that the root causes of the conflict should be re-addressed and resolved.

Keywords: Psychological trauma, Boko Haram victims, Zoning, Nigeria, Conflict resolution.

\section{Introduction}

The quest for leadership in Nigeria remains an issue for political tussle over the years. This was witnessed during the political era of the civilians from 1960 to 1966 and that of the military era from 1966 to 1979 as well as 1983 to 1999. Nigeria, a country with diverse ethnic nationalities and multi-religious worshipers is faced with a fact that leadership cannot be ignored but who to put in position of authority to lead is the major issue. However, the notion of ethnic differences begot the quest for leadership between the North and South.

As far back as 1914, the country before she gained her independence was ruled by the British authorities whom through their leadership amalgamated the North and South to form an entity called Nigeria. The country was ruled by the British authorities from her period of formation when the two protectorates were amalgamated in 1914 by the then leader, Lord Lugard. Afterward, Nigeria was under their leadership from 1914 to 1960 when she gained her independence. However, gaining independence from the white people still could not solve the ethnic differences within the context of majority and minority question between the periods of 1960 to 1966 (Akinboye and Anifowose, 2008).

The ethnic differences among other issues later led to the military takeover in 1966 and that created an environment for military rule from 1966 down to 1979 when the leadership of Gen. Olusegun Obasanjo conducted elections that ushered in the return to democratic rule on the $1^{\text {st }}$ of October, 1979. Nigeria as a nation, vastly endowed with diverse ethnic nationalities should rather serve as a source of unity in diversity for the purpose of promoting oneness 
amongst the people. This is one of the reasons why zoning of political positions came into place so that no section of the country would be left behind into the quest for power distribution among the different ethnic groups and to benefit the sharing formula between the North and South.

In this regard, between the periods of 1979-1983, the country's leadership came from the North under the leadership of Alhaji Shehu Shagari who hails from Sokoto State, while the Vice President came from the Southern part of the country in person of Chief Alex Ekwueme. This was done in such a way that, power was divided between the North and South in order to promote unity in diversity among the Nigerian people. Another view was to promote Nigerian unity through integration of religious diversity having the President, Shehu Shagari as a Muslim and the Vice-President, Alex Ekwueme as a Christian (Ayantayo, 2009).

This is the same practice as it was introduced in 1999 when the Military handed over power to a democratically elected government under the leadership of President Olusegun Obasanjo and Vice-President Atiku Abubakar of whom the President was a Christian and that of the Vice, a Muslim. Again power was divided between the North and South since the President came from the South and the Vice from the North. The arrangement was made for the purpose of power sharing between the North and South periodically. However, the zoning/rotation of power between the North and South only lasted from 1999-2007 since it was truncated in 2011 and that created an atmosphere for conflict in Nigeria.

\section{Objectives of the Paper}

The objectives of the research paper therefore are:

i. To seek redress on how the conflict between the North and South can be resolved for the purpose of achieving a harmonious relationship between the two regions, and enhancing political stability within the country Nigeria.

ii. To bring to the fore, the psychological trauma that the victims of the Boko Haram attack went through.

iii. To bridge the gap between the six geopolitical regions for the purpose of enhancing peace and security, and uniting the ethno-religious differences in Nigeria.

\section{Theoretical Framework}

This work intends to fixture in the integration theory which is classified into three major descriptions namely subnational, national and international. However, the paper focuses on subnational and national to reflect the content therein. The big question is why integration theory? How then can it be applicable to this work? The work of Lijphart (1971) has been looked at, and it brings the integration theory into the different dimensions that have been mentioned above, and it is intended to be used in analyzing this work, as subnational refers to the states of the federation in Nigeria and national in the dimension of integrating the people of Nigeria who are from different ethnic backgrounds and a variation of religious backgrounds. The country is subdivided into thirty-six (36) States of the federation and these States are represented within the context of six geo-political zones. This work aims at promoting unity in diversity through the integration of the people from all perspectives.

\section{Discussion}

\subsection{The Historical Background: Analyzing the historical background of Nigerian leadership.}

Table 1: The leadership of Nigeria between the North and South 1966-2015

\begin{tabular}{cccc}
\hline S/No. & Name (Head of State/President) & Region & Religion \\
\hline 1 & Gen. Yakubu Gowon (1966-1975) & North & Christian \\
2 & Gen. Murtala Mohammed (1975-1976) & North & Muslim \\
3 & Major-Gen. Olusegun Obasanjo (1976-79) & South & Christian \\
4 & President Shehu Shagari (1979-1983) & North & Muslim \\
5 & Major-General M. Buhari (1983-1985) & North & Muslim \\
6 & Gen. Ibrahim Babangida (1985-1993) & North & Muslim \\
7 & Ernest Shonekan (1993-1993) & South & Christian \\
8 & Gen. Sani Abacha (1993-1998) & North & Muslim \\
9 & Gen. Abdulsalami Abubakar (1998-1999) & North & Muslim \\
\hline
\end{tabular}




\begin{tabular}{clcc}
\hline Term & The Return of Nigerian Democratic Rule in 1999 & & \\
\hline $1999-2003$ & President Olusegun Obasanjo (4 years) & South & Christian \\
$2003-2007$ & President Olusegun Obasanjo (4 years) & South & Christian \\
$2007-2010$ & President Umaru Yar'Adua (2 years ) 341 days & North & Muslim \\
$2010-2011$ & President Goodluck Jonathan (1 year) 25 days & South & Christian \\
$2011-2015$ & President Goodluck Jonathan (4 years) & South & Christian \\
\hline
\end{tabular}

Source: Akinboye and Anifowose, (2008); and Ayantayo, (2009).

\subsection{The Military Rule in Nigeria}

The Table 1 above, took a dimension of understanding how the Nigerian State has been ruled by her leaders from 19662015 with the view of providing a deeper understanding on what created the atmosphere that led to the conflict between the North and South. From the table as seen above, from 1966-1979, those were the days and years of military rule in Nigeria. The military government took over power from the civilian on the $15^{\text {th }}$ of January, 1966 after the coup which was organized by the Igbo from the Southern (Present South-East) part of the country. The coup took away the lives of many prominent Northerners such as the Sultan of Sokoto, Ahmadu Bello and the Prime Minister of Nigeria, Sir Abubakar Tafawa Balewa (Akinboye and Anifowose, 2008).

The Northerners on the other hand, organized another counter coup that led to the killing of the Nigerian Head of State, Major-General Johnson Aguiyi-Ironsi. After that, a Northerner, a Christian and of minority ethnic group was made the Head of State of Nigeria, General Yakubu Gowon by the Hausa-Fulani within the military who were and are the major ethnic group from the North and mostly of Islamic faith. General Yakubu Gowon was the first and only Christian from the North who has ruled Nigeria (Akinboye and Anifowose, 2008).

Nigerian political system under the military was largely controlled and ruled by the Northern hegemony as witnessed during the Yakubu Gowon led administration 1966-1975, then Murtala Mohammed took over power from 19751976 when he was assassinated on the $13^{\text {th }}$ of February, 1976. That created an avenue for the South to rule through Major-General Olusegun Obasanjo 1976-1979 when he conducted elections and handed over power to the civilian led government on the $1^{\text {st }}$ of October, 1979. However, the civilian government lasted for only four years 1979-1983 when the military again came into power through another coup that brought in Major-General Muhammadu Buhari, 1983-1985, who is presently the President of Nigeria with tenure of four years from May 29th, 2015 to May 29th 2019.

Military coups as well known in Nigeria were days when the Constitution was suspended by the Military Government. The military ruled for fifteen years covering 1983-1999, under Buhari 1983-1985, Babangida 1985-1993, Abacha 1993-1998 and Abdulsalami Abubakar 1998-1999. All these years 1979-1999 as seen in table 1, they were ruled by the North and of Muslim faith exception of Chief Ernest Shonekan, who led the country as Interim Head of Government from August, 1993 to November, 1993 who was from the Southern part of the country. In order to promote Peace and Unity within the country, the same Northerners through the leadership of General Abdulsalami Abubakar, in 1999 handed over power to the South under the leadership of Olusegun Obasanjo. That was the ushering in of the return to democratic rule after many years of military rule (Akinboye and Anifowose, 2008).

\subsection{The Civilian and Democratic Rule in Nigeria}

The quest for national unity and promotion of peace within the country under the democratic led government in 1999 was the major reason behind the introduction of the zoning formula and rotation of the presidency between the North and South as enshrined into the Peoples Democratic Party's (PDP) Constitution. The party was the ruling political party that won the 1999 general elections during the return to democratic rule. The principle of zoning was aimed at integrating all the six geopolitical zones into a whole and a federation of one people. This was demonstrated from 1999-2007 when all the six-geopolitical zones were equally represented into the government at the federal level in order to promote peace and political stability within the country as seen in table 2 below. 
Table 2: The Integrated zones in Nigeria 1999-2007

\begin{tabular}{clccc}
\hline S/No. & Position & Zone & Duration & Religion \\
\hline 1 & President & South-West & 8 years & Christian \\
2 & Vice-President & North-East & 8 years & Muslim \\
3 & Senate President & South-East & 8 years & Christian \\
4 & Speaker, Federal House of Representatives & North-West & 8 years & Muslim \\
5 & Secretary to the Government of the Federation & South-South & 8 years & Christian \\
6 & Chairman of the Ruling Party & North-Central & 8 years & Christian/Muslim \\
\hline
\end{tabular}

Source: Awopeju, Adelusi and Oluwashakin (2012); and Ayantayo, (2009).

From the table 2 above, we can see how the country was made to share the six top positions in Nigeria amongst the six geopolitical zones in order to give equal representation of the people through integration of the whole country. The President came from the South-West, and of Christian faith, he ruled the country for eight years 1999-2007 after the North handed over power to the South. The Vice-President, from the North-East and he was of Islamic faith. This was made possible in order to strike a balance between the North and South, Christians and Muslims for the purpose of equal representation and peace building in Nigeria. Again, all the zones were represented within that government; the North Central and South-South which are dominant areas of the minority ethnic groups in Nigeria were equally represented. In 2007, after the eight years of presidency in the Southern part of the country, power was shifted to the North when the Late President Yar'Adua came into power but later died on the $5^{\text {th }}$ of May, 2010 as a result of ill health.

At this time, the Vice-President from the South was sworn in as the President on the $6^{\text {th }}$ of May, 2010 to complete their tenure of four years 2007-2011. President Jonathan being a Christian from the Southern part of the country was pushed with his ambition to run for the 2011 general elections, which brought in the truncated zoning arrangement within the PDP which was enshrined in their constitution. This is where some quarters from the North resisted and fought against the truncated zoning in view of the fact that power was supposed to remain in the North for eight years 2007-2015 before shifting back to the South in 2015. President Jonathan used the incumbency power against his own party's constitutional zoning or rotation of power between the North and South which was actually within the PDP's constitution. This created a climate for conflict and resulted into the usage of the Boko Haram as a tool as posited by the Late General Andrew Azazi (Ekwueme and Obayi, 2012; Liman, 2014).

In the views of Andrew Azazi, the PDP got it wrong for not allowing the North to rule in 2011-2015 to have completed the eight years of presidency in the North since it was their constitutional arrangement to have power in the South 1999-2007 and same should have been the position of the North 2007-2015. He further argued that, since the zoning was truncated, the Boko Haram became better equipped and better funded with sophisticated weapons to fight against the government that was led by President Jonathan whose political ambition led to the conflict therein between the North and South. The situation that created the Boko Haram sect against the government must be tackled if not, arresting the leaders of Boko Haram would not end the problem (Liman, 2014).

\subsection{The Psychological Trauma on Boko Haram's Victims}

In view of fighting against the government and the people of Nigeria, many people have been affected by the attacks of the Boko Haram insurgents. Many have been killed through bombing, some through the usage of gun against their lives by the Boko Haram. And to some, their parents and siblings were kidnapped by the Boko Haram and that created an atmosphere that led to their passing through psychological trauma. These incidences are recorded in many instances such as the Chibok girls that were kidnapped, the agony of those living in camps such as the Internally Displaced Persons (IDP Camps) and those who are staying in refugee camps in Cameroon, Niger and Republic of Chad (United Nations High Commissioner for Refugees, 11 November, 2014; United Nations High Commissioner for Refugees, 16 February, 2015; Ayansina, 2015).

In the case of the Chibok Girls, some of their parents were affected as a result of psychological trauma that led to their death since they could no longer cope with the situation as it became unbearable for them. That led them to their early grave. According to Biodun (2014) some of the parents whom their daughters were abducted by the Boko Haram on the 14th of April, 2014 such as Mrs Mary Paul Lalai who could not bear the incidence that took place. She went through psychological trauma and that affected her to an extent that she could not survive but later died of heart attack without seeing her daughter. 
Another parent, Mutai Hona, also died of heart failure as a result of the kidnap of his two daughters who were in the hands of the Boko Haram. This occurred after he watched the video that was released by the Boko Haram on a note that, the girls would be married out without the consent of their parents and some of the girls that were Christians were converted to Islam by the insurgents (Sahara Reporters, 2014). President Jonathan was called upon by several groups both locally and internationally for his led government to rescue the girls from the hands of Boko Haram. Such calls also came from Malala Yousafzai who visited Nigeria on the occasion of her birthday to speak for the girls as her sisters whose voices were not heard (Ehikioya, 2014).

The agony of children as a result of the Boko Haram attacks also remains another level of psychological trauma since the parents could not cater for them as ought to be. According to UNICEF (2015) the displaced children under the care of the UN Agency noted that, over 1.4 million children have been displaced and that they could not take care of them since their number continues to grow beyond what they could do for the children whom about 1.2 million are from Nigeria out of the total number of 1.4 million children. Such are some of the traumas that the people are faced with which reasonably, a call for a resolution of the conflict is very necessary and not just for those who are directly or indirectly affected by the crisis over time. This is where we will introduce the new model for zoning formula and rotation of the presidency between the North and South.

Table 3: Zoning Formula Model One

\begin{tabular}{|c|c|c|c|c|c|c|c|c|}
\hline S/No. & Position & Region & Religion & Ethnicity & Position & Region & Religion & Ethnicity \\
\hline 1 & President & North & $M$ & $\begin{array}{l}\text { M1 } \\
\text { NW }\end{array}$ & A & South & $\mathrm{C}$ & $\begin{array}{l}\mathrm{M} 1 \\
\mathrm{SE}\end{array}$ \\
\hline 2 & Vice President & South & C & $\begin{array}{l}\text { M1 } \\
\text { SE }\end{array}$ & B & North & M & $\begin{array}{l}\text { M1 } \\
\text { NE }\end{array}$ \\
\hline 3 & Senate President & North & $\mathrm{M} / \mathrm{C}$ & $\begin{array}{l}\text { M2 } \\
\text { NC }\end{array}$ & C & South & $\mathrm{C} / \mathrm{M}$ & $\begin{array}{l}\text { M2 } \\
\text { SS }\end{array}$ \\
\hline 4 & Speaker & South & $\mathrm{C} / \mathrm{M}$ & $\begin{array}{l}\text { M1 } \\
\text { SW }\end{array}$ & D & North & $M / C$ & $\begin{array}{l}\text { M1 } \\
\text { NW }\end{array}$ \\
\hline 5 & Secretary F G & North & $\mathrm{M} / \mathrm{C}$ & $\begin{array}{l}\mathrm{M} 1 \\
\mathrm{NE}\end{array}$ & $E$ & South & $\mathrm{C} / \mathrm{M}$ & $\begin{array}{l}\text { M1 } \\
\text { SW }\end{array}$ \\
\hline 6 & Party Chairman & South & $\mathrm{C} / \mathrm{M}$ & $\begin{array}{l}\text { M2 } \\
\text { SS }\end{array}$ & $\mathrm{F}$ & North & $\mathrm{M} / \mathrm{C}$ & $\begin{array}{l}\mathrm{M} 2 \\
\mathrm{NC}\end{array}$ \\
\hline
\end{tabular}

Source: Developed by the Authors in 2015.

Table 4: Zoning Formula Model Two

\begin{tabular}{|c|c|c|c|c|c|c|c|c|}
\hline S/No. & Position & Region & Religion & Ethnicity & Position & Region & Religion & Ethnicity \\
\hline 1 & President & North & $\mathrm{C}$ & $\begin{array}{l}\mathrm{M} 2 \\
\mathrm{NC}\end{array}$ & A & South & M & $\begin{array}{l}\text { M2 } \\
\text { SS }\end{array}$ \\
\hline 2 & Vice President & South & M & $\begin{array}{l}\text { M1 } \\
\text { SW }\end{array}$ & B & North & C & $\begin{array}{l}\text { M1 } \\
\text { NW }\end{array}$ \\
\hline 3 & Sen. President & North & $\mathrm{C} / \mathrm{M}$ & $\begin{array}{l}\mathrm{M} 1 \\
\mathrm{NE}\end{array}$ & C & South & $\mathrm{M} / \mathrm{C}$ & $\begin{array}{l}\text { M1 } \\
\text { SW }\end{array}$ \\
\hline 4 & Speaker & South & $M / C$ & $\begin{array}{l}\text { M2 } \\
\text { SS }\end{array}$ & D & North & $\mathrm{C} / \mathrm{M}$ & $\begin{array}{l}\text { M2 } \\
\text { NC }\end{array}$ \\
\hline 5 & Secretary & North & $\mathrm{C} / \mathrm{M}$ & $\begin{array}{l}\text { M1 } \\
\text { NW }\end{array}$ & E & South & $\mathrm{M} / \mathrm{C}$ & $\begin{array}{l}\text { M1 } \\
\text { SE }\end{array}$ \\
\hline 6 & Party Chairman & South & $M / C$ & $\begin{array}{l}\text { M1 } \\
\text { SE }\end{array}$ & $\mathrm{F}$ & North & $\mathrm{C} / \mathrm{M}$ & $\begin{array}{l}\mathrm{M} 1 \\
\mathrm{NE}\end{array}$ \\
\hline
\end{tabular}

Source: Developed by the Authors in 2015. 
Table 5: Zoning Formula Model Three

\begin{tabular}{|c|c|c|c|c|c|c|c|c|}
\hline S/No. & Position & Region & Religion & Ethnicity & Position & Region & Religion & Ethnicity \\
\hline 1 & President & North & M & M1 & $A$ & South & C & M1 \\
\hline & & & & $\mathrm{NE}$ & & & & SW \\
\hline 2 & Vice President & South & C & $\begin{array}{l}\text { M2 } \\
\text { SS }\end{array}$ & B & North & M & $\begin{array}{l}\text { M2 } \\
\text { NC }\end{array}$ \\
\hline 3 & Sen. President & North & $M / C$ & $\begin{array}{l}\text { M1 } \\
\text { NW }\end{array}$ & c & South & $\mathrm{C} / \mathrm{M}$ & $\begin{array}{l}\text { M1 } \\
\text { SE }\end{array}$ \\
\hline 4 & Speaker & South & $\mathrm{C} / \mathrm{M}$ & $\begin{array}{l}\text { M1 } \\
\text { SE }\end{array}$ & D & North & $M / C$ & $\begin{array}{l}\text { M1 } \\
\text { NE }\end{array}$ \\
\hline 5 & Secretary & North & $M / C$ & $\begin{array}{l}\text { M2 } \\
\text { NC }\end{array}$ & E & South & $\mathrm{C} / \mathrm{M}$ & $\begin{array}{l}\text { M1 } \\
\text { SS }\end{array}$ \\
\hline 6 & Party Chairman & South & $\mathrm{C} / \mathrm{M}$ & $\begin{array}{l}\text { M1 } \\
\text { SW }\end{array}$ & $\mathrm{F}$ & North & $\mathrm{M} / \mathrm{C}$ & $\begin{array}{l}\text { M1 } \\
\text { NW }\end{array}$ \\
\hline
\end{tabular}

Source: Developed by the Authors in 2015.

This zoning formula model is designed to reflect the period of leadership of Nigeria in the context of power sharing between the North and South, representation of both Christians and Muslims, as well as a representation of all the six geopolitical zones namely North-West, North-Central, North-East, South-East, South-South and South-West. This model captures a period of 30 years in governance to give equal opportunity to all the six geopolitical zones in Nigeria to rule for a five years single tenure.

In Model One, the President is zoned to the North-West in order to give opportunity to one of the major ethnic groups in Nigeria, the Hausa-Fulani to rule for five years single tenure. The Vice-President zoned to the South-East to have the Igbo representation. After the tenure, power would be zoned to the South-East to give opportunity for the Igbo to rule as President of Nigeria while the Vice-President zoned to North-East.

In Model Two, the Presidency goes back to the North with the zoning to North-Central where the minority Christians are given the opportunity to rule and the Vice-President zoned to the South-West to have a Muslim as the second in command of leadership. This would be done through the process of integrating the whole country with her diverse ethnic and religious backgrounds. However, after the period of 30 years, the next zoning to North-Central, a Muslim would be the President and the Vice from South-West as a Christian. Model Two, again provides opportunity for the South-South to rule as President and Vice-President be zoned to the North-West.

Model Three, the position of the President is zoned to North-East and that of the Vice-President to South-South for a period of five years. After which power would be shifted to South-West where the President is zoned and VicePresident to the North-Central. All these three models allows leadership in place for only one single tenure of five years and power sharing between the North and South in order to promote the spirit of unity and peace

\section{Findings}

The findings from this research thus revealed that, the truncated zoning arrangement in 2011 which presented it-self for President Jonathan to contest for the 2011 presidential elections created the atmosphere that resulted into conflict between the North and South. These issues were centered around the constitution debates on who to contest and who not to contest. The North felt it was their turn for them to rule the country since the South had ruled from 1999-2007 and as such 2007-2015 should have been the turn of the North but since the zoning was truncated, political conflict settled in as the root causes of the Boko Haram attacks which the late Gen. Andrew Azazi called for the redress of the said issues.

The finding also reveals that, many people have been affected by the Boko Haram attacks leading to psychological trauma. Some of the victims of the Boko Haram attacks whom were psychologically affected were the parents of the Chibok girls that were abducted by the Boko Haram insurgents during the $14^{\text {th }}$ of April, 2014 attack on their secondary school in Chibok, Nigeria. The research therefore, calls for the resolution of the root causes of the conflict which was centered on zoning and rotation of the presidency between the North and South.

\section{Conclusion}

In conclusion, the Nigerian State cannot move forward if there is no security for the masses and the polity in question. 
Thus, the conflict between the North and South can only be resolved when there is fair sharing of power between the two regions and across the six geopolitical zones as states in the zoning formula model which is developed and introduced by the researchers and authors of this paper. It is therefore recommended that, the Federal Government of Nigeria should adopt this model and it should be enshrined into the Nigerian Constitution for the purpose of promoting peace, resolving the North and South political tussle, and providing a stable political atmosphere in Nigeria. This should be done through the constitutional amendment in order to accommodate the six geopolitical zones and rotational presidency as proposed in the zoning formula model as a tool for resolving the said root causes of the conflict therein.

\section{References}

Akinboye, S. O. and Anifowose, R. (2008) Nigerian Government and Politics, Elements of Politics, edited by Anifowose, R. \& Enemuo, F., Sam Iroanusi Publications, Lagos.

Awopeju, A., Adelusi, O. and Oluwashakin, A. (2012) Zoning Formula and the Party Politics in Nigeria Democracy: A Crossroad for PDP in 2015 Presidential Election, Research on Humanities and Social Sciences, Vol. 2, No. 4 Ayansina, C. (2015) We've 981,416 internally displaced persons in Nigeria - FG, Retrieved from http://www.vanguardngr.com/2015/01/weve-981416-internallydisplaced-persons- nigerria-fg/, Accessed 1st/August/2015.

Ayantayo, J. K. (2009) Religious Factors in the Nigerian Public Sphere: Burdens and Prospects, Africa Development, Vol. XXXIV, Nos 3 $\& 4$.

Biodun, K., (2014) Chibok: Mother of Abducted Girl Dies, Retrieved from http://thenationonline ng.net/new/chibok-mother-abducted-girldies/, Accessed 19/September/2015.

Ehikioya, A., (2014) Jonathan to Meet Parents of Abducted Girls, Retrieved from http://thenationonlineng.net/new/jonathan-to-meetparents-of-abducted-girls/, Accessed 19/September/2015.

Ekwueme, A. C. and Obayi, P. M. (2012) Boko Haram Assault on Nigeria: Towards Effective Mass Media Response, New Media and Mass Communication, Vol 5.

Lijphart, A. (1971) Cultural Diversity and Theories of Political Integration, Canadian Journal of Political Science, Vol. 4, No. 1, March, pp. 1-14.

Liman, A. (2014) Boko Haram: Why the Northerners Believe Jonathan is Guilty, Retrieved from http://leadership.ng/features/396929/boko-haram-northerners-believe-jonathan-guilty Accessed 9/September/2015.

Olaiya, T. A., Apeloko, D. O., Amanchukwu, I. N. and Shiyanbade, B. W. S. (2014) Rethinking Zoning Formula as Political Panacea for Ethnic Conflict and Governance Crisis in Nigeria, Research on Humanities and Social Sciences, Vol. 4, No. 26.

Sahara Reporters, (2014) Father of Two Girls Kidnapped in Chibok Has Died, Second Such Report, Retrieved from http://newsrescue.com/father-two-girls-kidnapped-chibok-died-second-report/\#axzz3m9ROCCl7, Accessed 19/September/2015.

United Nations High Commissioner for Refugees, (2014, November 11) Boko Haram attacks in Nigeria force 13,000 to flee to Cameroon, Retrieved from http://www.unhcr.org/5462288 96.html, Accessed 24/July/2015.

United Nations High Commissioner for Refugees, (2015) 2015 UNHCR Country Operations Profile - Chad, Retrieved from http://www.unhcr.org/pages/49e45c226.html, Accessed 30/July/2015.

United Nations High Commissioner for Refugees, (2015, February 16) As Violence Spreads beyond Nigeria - UNHCR takes Action, Retrieved from http://www.unrefugees.org /2015/02/nigeria-violence-spreads-unhcr-takes-action/, Accessed 30/July/2015.

UNICEF (2015, September 19) Boko Haram Displaced Children Now Over 1.4 Million, Retrieved from http://leadership.ng/news/461825/boko-haram-displaced-children-now-over-1-4-million-unicef, Accessed 19/September/2015. 